\title{
Molecular Characterization of the Cucurbit Yellow Stunting Disorder Virus Coat Protein Gene
}

\author{
Ioannis C. Livieratos, Apostolos D. Avgelis, and Robert H. A. Coutts
}

First and third authors: Department of Biology, Imperial College of Science, Technology and Medicine, Sir Alexander Fleming Building, Imperial College Road, London SW7 2AZ, England; and second author: Plant Protection Institute, GR-71110 Iraclion, Greece. Accepted for publication 25 July 1999.

\begin{abstract}
Livieratos, I. C., Avgelis, A. D., and Coutts, R. H. A. 1999. Molecular characterization of the cucurbit yellow stunting disorder virus coat protein gene. Phytopathology 89:1050-1055.

Cucurbit yellow stunting disorder virus (CYSDV) is a partially characterized bipartite closterovirus transmitted by the tobacco whitefly (Bemisia tabaci). CYSDV has emerged as a serious pathogen in southeastern Spain and the Mediterranean Region, causing yellowing disease of cucumber and melon crops. Using a modified reverse-transcription polymerase chain reaction protocol with gel-extracted dsRNA templates, fragments of CYSDV RNA2 were amplified and cloned. Sequence analysis of the cloned fragments revealed open reading frames encoding the heat shock

ilar to that of lettuce infectious yellows virus (LIYV) RNA2. The complete CYSDV CP gene is $756 \mathrm{nt}$ long and encodes a protein with a molecular mass of $28.5 \mathrm{kDa}$. A comparison of the amino acid sequence of the CYSDV $\mathrm{CP}$ gene with those of other closteroviruses revealed significant levels of similarity with sweet potato chlorotic stunt virus and LIYV (36 and 27\%, respectively), both of which are members of the recently proposed Crinivirus genus of closteroviruses. The complete CYSDV CP gene was cloned into a bacterial expression vector, and the resulting fusion protein was purified and used to produce antiserum. Purified immunoglobulins specifically detected CYSDV in infected plant extracts, both in immunoblot and indirect enzyme-linked immunosorbent assays with a titer exceeding 2,000 times for both assays.
\end{abstract} protein 70 homolog, two proteins of unknown function (p58 and p9), and the coat protein $(\mathrm{CP})$ of the virus in a contiguous gene arrangement sim-
Additional keyword: coat protein expression.
Until recently, the taxonomy of the family Closteroviridae typically included aphid- and mealybug-transmitted viruses with large monopartite genomes encapsidated in extremely long, flexuous particles $(1,200$ to $2,000 \mathrm{~nm})(28)$. Closteroviruses are distinguished by the presence of a heat shock protein 70 (HSP70) homolog gene and a diverged coat protein duplicate (CPd) gene, as well as the formation of characteristic membranous vesicles in the cytoplasm of infected phloem cells (1). The whitefly-transmitted lettuce infectious yellows virus (LIYV), which shares typical closterovirus cytopathology (10) and a genome organization that consists of two RNA segments (18), initially was classified together with all closteroviruses. LIYV, however, is now considered the prototype member of the bipartite, whitefly-transmitted closteroviruses forming the genus Crinivirus in the family Closteroviridae (25).

Criniviruses have emerged as a new group of economically important viruses and include tomato infectious chlorosis virus (36), tomato chlorosis virus (35), sweet potato chlorotic stunt virus (SPCSV; 14,27), cucurbit yellow stunting disorder virus (CYSDV; 3,13), and possibly lettuce chlorosis (LCV; 11) and beet pseudo-yellows viruses (BPYV; 9), whose bicomponent genome status has yet to be confirmed. Among the whitefly-transmitted viruses, BPYV and CYSDV cause economically important yellowing diseases on cucurbits, especially in the Mediterranean Region $(3,5,24)$. BPYV is transmitted exclusively by Trialeurodes vaporariorum (Westwood), is found worldwide, and has a wide host range (9). Conversely, CYSDV is transmitted by Bemisia tabaci (Gennadius), only infects members of the family Cucurbitaceae, and appears to be restricted to the Mediterranean Region and the Middle East $(3,13,34)$. Nevetheless, due to the common biological characteristics of the two

Corresponding author: R. H. A. Coutts; E-mail address: r.coutts@ic.ac.uk

Publication no. P-1999-0922-01R

(C) 1999 The American Phytopathological Society viruses (symptomatology, host range, and geographic distribution), differentiation between them in the field is difficult.

Sequence information on the genomes of both BPYV and CYSDV is limited. The genome of CYSDV consists of two RNA species of $\approx 9$ and $8 \mathrm{~kb}(3)$. The full sequence of the BPYV genome, which is probably synonymous for cucumber yellows (38), muskmelon yellows (15), and cucumber chlorotic spot (37) viruses, has been described but is not generally available. Small fragments of the HSP70 homolog genes of both BPYV and CYSDV have been amplified with degenerate primers $(32)$ or randomly cloned $(3,5,6)$, enabling the development of reverse-transcription polymerase chain reaction (RTPCR) and hybridization assays to differentiate between the two viruses (24). Our recent (24) and previous works (3) showed that the most prevalent yellowing disease of cucurbits in southeastern Spain currently is caused by CYSDV, due to the progressive displacement of $T$. vaporariorum by $B$. tabaci over the last few years.

The emergence of CYSDV as a destructive pathogen in the Mediterranean Region necessitates studies of the CYSDV genome and development of diagnostic tests for the virus. We have chosen to clone and sequence parts of the virus genome and to identify the CYSDV coat protein (CP) gene for expression in bacterial cells and subsequent antibody production. Similar methods have been used for other closterovirus CPs, including beet yellows closterovirus (BYV; 2), LIYV (17), SPCSV (14), citrus tristeza virus (CTV; 26), beet yellow stunt closterovirus (BYSV; 16), and grapevine leafrollassociated virus-3 (GLRaV-3; 23). In this paper, we describe reliable immunoblot and indirect enzyme-linked immunosorbent assay (ELISA)-based detection methods for CYSDV and a phylogenetic comparison of the amino acid sequences of all presently known closterovirus CP genes, including CYSDV.

\section{MATERIALS AND METHODS}

Virus source and purification of dsRNAs. CYSDV was maintained in infected plants under greenhouse conditions in Almeria, 
Spain, following B. tabaci transmission of the virus (24). Melon and cucumber leaves with yellowing symptoms were supplied, respectively, by P. Kraakman (De Ruiter Research, Almeria, Spain) and J. Lambalk (Enza Zaden, Enkhuizen, the Netherlands). Viral dsRNA was extracted from infected leaves and subjected to DNase I and S1 nuclease treatment as described previously (24). Hybridization analysis with CYSDV- and BPYV-specific probes was performed according to Livieratos et al. (24) to exclude the possibility of a mixed infection.

Cloning of the CYSDV CP gene. To produce clones that extended in a $3^{\prime}$ direction on CYSDV RNA2 toward the putative CYSDV CP gene, a modified RT-PCR protocol was devised. Gelextracted CYSDV dsRNA (50 ng) was added to 100 pM CYSDV4specific primer (Fig.1; Table 1), and the mixture was denatured in $20 \mathrm{mM}$ methyl mercuric hydroxide for $20 \mathrm{~min}$ at room temperature. Primed RNA was used for first-strand cDNA synthesis with 200 units of Superscript II reverse-transcriptase (Gibco Laboratories, Grand Island, NY); synthesis was performed at $42^{\circ} \mathrm{C}$ for $50 \mathrm{~min}$. The reaction mixture was diluted in Tris-EDTA buffer and passed twice through a Centricon 100 column (Amicon, Beverly, MA). Several dilutions of purified cDNA were used as template for PCR amplification by a combination of the CYSDV4 primer and a hexamer primer (5'-ATGCGT-3'; $100 \mathrm{pM}$ ). Template cDNA was denatured at $96^{\circ} \mathrm{C}$ for $5 \mathrm{~min}$, and amplification was performed for 3 cycles of $30 \mathrm{~s}$ at $96^{\circ} \mathrm{C}, 45 \mathrm{~s}$ at $42^{\circ} \mathrm{C}$, and $2 \mathrm{~min}$ at $72^{\circ} \mathrm{C}$, followed by 32 cycles of $30 \mathrm{~s}$ at $96^{\circ} \mathrm{C}, 45 \mathrm{~s}$ at $55^{\circ} \mathrm{C}$, and $2 \mathrm{~min}$ at $72^{\circ} \mathrm{C}$, with a final extension step at $72^{\circ} \mathrm{C}$ for $5 \mathrm{~min}$. The viral specificity of PCR-amplified products was verified by Southern blotting and probing with an oligolabeled CYSDV-specific clone (24). PCR-amplified products subsequently were ligated into pGEM-T Easy vector (Promega, Madison, WI) according to the manufacturer's instructions and transformed into DH5 $\alpha$ Escherichia coli cells. Sequence information about the cloned DNA product was used to design another CYSDV-specific primer (CYSDV101; Fig. 1 and Table 1) for amplification of the putative CYSDV CP gene in RT-PCR experiments, as described above.

Sequences of cDNA clones were obtained by the Sanger chaintermination method, using dye-terminator cycle sequencing with AmpliTaq DNA polymerase FS (ABI PRISM 377). Sequence analysis was performed using the PileUp and BLAST programs (version 8.1, University of Wisconsin Genetics Computer Group, Madison) $(7,12)$, and a phylogenetic tree was constructed using the CLUSTAL X


$1 \mathrm{kbp}$

Fig. 1. Schematic representation of the genomic organization of lettuce infectious yellows virus (LIYV) RNA2 and the sequenced portions of cucumber yellow stunting disorder virus (CYSDV) RNA2. The location of oligonucleotide primers used in a modified reverse-transcription polymerase chain reaction protocol (CYSDV2, CYSDV4, and CYSDV 101) and the sizes of the products generated are shown. The location of oligonucleotide primers (CP1 and CP2) used for amplification of the CYSDV coat protein open reading frame, prior to cloning in an expression vector, also are shown. program (31). Transformation, Southern blot analysis, and DNA manipulation were as described by Sambrook et al. (29).

Construction of the CYSDV CP expression vector. To express the CYSDV CP in E. coli, a 775-bp DNA fragment containing the entire putative CP open reading frame (ORF) was amplified from viral dsRNA2 by RT-PCR. The method was basically as described above, with the omission of the PCR cycles at a low annealing temperature $\left(42^{\circ} \mathrm{C}\right)$ and with two virus-specific 30 -mer oligonucleotide primers (CP1 and CP2; Table 1). CP1 comprised the first $20 \mathrm{nt}$ of the CP ORF and 10 additional nucleotides, including an extra A residue and a $S m a I$ site immediately upstream of the start codon for expression and cloning purposes, respectively. CP2 comprised the complement of the last $20 \mathrm{nt}$ of the $\mathrm{CP}$ ORF, including the termination codon and, immediately downstream, an EcoRI site for cloning purposes. The PCR-amplified product was cloned into pGEM-T Easy vector to produce pGEM-CP, and the DNA was transformed into E. coli, as described above. After digestion of pGEM-CP with SmaI and SacI, an 819-bp fragment (including the entire CP ORF) was gel-purified from agarose, using a QIAEX kit (Qiagen, Hilden, Germany), and ligated to a similarly digested pGEX-KG expression vector (a modified PGEX$2 \mathrm{~T}$ vector [Pharmacia, Uppsala, Sweden] containing a glycine-based linker, PGISGGGGG, inserted immediately downstream of the thrombin cleavage site) to produce pGEX-CYSDVCP. The correct ORF for expression and $\mathrm{CP} \mathrm{ORF}$ sequence in the recombinant plasmid was verified by sequencing, as described above.

Expression of CYSDV CP in $E$. coli, purification of fusion protein, and antiserum production. The pGEX-CYSDVCP recombinant was transformed into $E$. coli BL21 cells that were grown at $37^{\circ} \mathrm{C}$ until they reached $A_{600 \mathrm{~nm}}=0.5$ to 0.6 and induced with $0.1 \mathrm{mM}$ isopropyl-thio- $\beta$-D-galactopyranoside for $3 \mathrm{~h}$ at $25^{\circ} \mathrm{C}$. Sonication and clarification of lysates were as described previously (30). Soluble recombinant protein, which consisted of the fulllength CYSDV CP fused to a glutathione- $S$-transferase (GST) tag, was partially affinity-purified with Sepharose $4 \mathrm{~B}$, following the manufacturer's instructions (Pharmacia). Fusion protein was purified to near homogeneity after $10 \%$ sodium dodecyl sulfate-polyacrylamide gel electrophoresis (SDS-PAGE) (20), staining with $0.3 \mathrm{M}$ copper chloride (21), and electroelution of the GST-CYSDVCP antigen (22). Finally, recombinant protein was concentrated with a Centricon column 30 (Amicon). The quality of the purified antigen was assessed after 10\% SDS-PAGE and Coomassie blue staining of gels, whereas concentrations were determined by a BCA protein assay (Pierce Chemical Co., Rockford, IL). Polyclonal antibodies were raised in a rabbit by administering three intramuscular injections over a 3 -week period on days 1, 8, and 20, using 108, 210 , and $240 \mu \mathrm{g}$ of purified GST-CP, respectively, emulsified with an equal volume of Freund's adjuvant. Ten days after the last injection the rabbit was bled, and rabbit immunoglobulin $\mathrm{G}$ (IgG) was purified according to the method of Clark and Adams (4).

Immunoblotting and indirect ELISA. For immunoblotting, $0.1 \mathrm{~g}$ of fresh leaf samples was homogenized in liquid nitrogen and extracted in $1 \mathrm{ml}$ of buffer (100 mM Tris- $\mathrm{HCl}$ [pH 8.0], 10 mM EDTA, $5 \mathrm{mM}$ dithiothreitol). Samples $(30 \mu \mathrm{l})$ were mixed with Laemmli's sample buffer (20) and analyzed by $12 \%$ SDS-PAGE.

TABLE 1. Specific oligonucleotide primers used for reverse-transcription polymerase chain reaction (RT-PCR) amplification of cucumber yellow stunting disorder virus (CYSDV) RNA2 and the CYSDV coat protein (CP) gene

\begin{tabular}{ll}
\hline Primer & Primer sequence $^{\mathrm{a}}$ \\
\hline CYSDV4 & GATGTGATGAATTACTGTGCTA $(+)$ \\
CYSDV2 & TTGGGCATGTGACATAGAG $(-)$ \\
CYSDV101 & CTTCCTGAACACATAGATGAA $(+)$ \\
CP1 & CATCCCGGGAATGGCGAGTTCGAGTGAGAA $(+)$ \\
CP2 & GTAGAATTCTCAATTACCACAGCCACCTG $(-)$
\end{tabular}

${ }^{a}$ Restriction sites for SmaI in CP1 and EcoRI in CP2 are underlined, and an additional A residue in CP1 is shown in bold. Primer sequences are shown in a $5^{\prime}-3^{\prime}$ orientation, and the polarity is indicated in parentheses. 
Electroblotting of separated proteins on Immobilon-P membrane (Millipore, Bedford, MA) was performed according to the method of Towbin et al. (33), using a transfer electroblot unit (Bio-Rad Laboratories, Hercules, CA). Immunoblots were blocked for $1 \mathrm{~h}$ in $1 \%$ (wt/vol) skim milk in $1 \times$ phosphate-buffered saline containing $0.1 \%$ Tween 20 (PBS-T). After blocking, immunoblots were reacted with purified anti-GST-CYSDVCP IgG, followed by alkaline phosphatase (AP)-conjugated goat anti-rabbit IgG (Sigma Chemical Co., St. Louis) at a 1:20,000 dilution. To visualize antibody-specific proteins, membranes were exposed to nitro blue tetrazolium chloride $(0.33 \mathrm{mg} / \mathrm{ml})$ and 5-bromo-4-chloro-3-indolyl phosphate and toluidine salt $(0.165 \mathrm{mg} / \mathrm{ml})$ in AP substrate buffer $(0.1 \mathrm{M}$ Tris$\mathrm{HCl}$ [pH 9.5], $0.1 \mathrm{NaCl}, 50 \mathrm{mM} \mathrm{MgCl}_{2}$ ). Membranes were washed thoroughly in PBS-T between each step.

For indirect ELISA, $1 \mathrm{~g}$ of leaf tissue was homogenized in $10 \mathrm{ml}$ of coating buffer $\left(14 \mathrm{mM} \mathrm{Na}_{2} \mathrm{CO}_{3}, 35 \mathrm{mM} \mathrm{NaHCO} 3,3 \mathrm{mM} \mathrm{NaN}_{3}\right.$ [pH 9.6]). ELISA plates were coated with $200 \mu \mathrm{l}$ of plant extracts and incubated at $4^{\circ} \mathrm{C}$ overnight. Immunoglobulins $(1 \mathrm{mg} / \mathrm{ml})$ raised against the GST-CYSDVCP fusion protein (1:500 dilution) were added and incubated at $37^{\circ} \mathrm{C}$ for $2 \mathrm{~h}$ before $200 \mu \mathrm{l}$ of 1:5,000 dilution, AP-labeled goat anti-rabbit IgG was applied. After incubation for $2 \mathrm{~h}$ at $37^{\circ} \mathrm{C}, 200 \mu \mathrm{l}$ of freshly prepared $p$-nitrophenyl phosphate $(1.0 \mathrm{mg} / \mathrm{ml})$ in $0.1 \mathrm{M}$ diethylamine substrate buffer ( $\mathrm{pH} 9.8)$

A

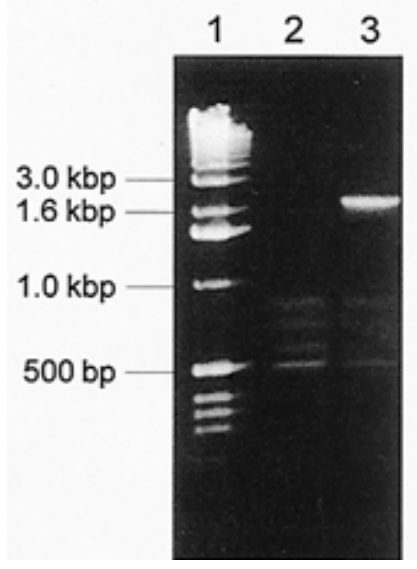

B

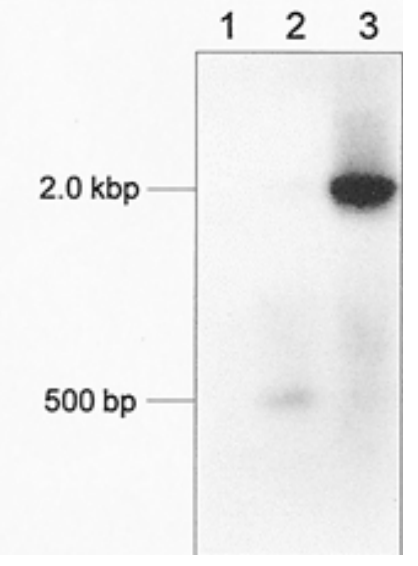

Fig. 2. A, Electrophoretic analysis in a $1 \%$ agarose gel of reverse-transcription polymerase chain reaction-amplified products with a CYSDV4 cucumber yellow stunting disorder virus (CYSDV)-specific oligonucleotide primer and a second arbitrary primer (lane 3) or with CYSDV4 oligonucleotide primer alone (lane 2). B, Southern blot of A probed with a ${ }^{32} \mathrm{P}$-labeled CYSDV specific clone (24). Lane 1 contains DNA molecular size markers (Gibco Laboratories); sizes are indicated to the left of each panel.

A

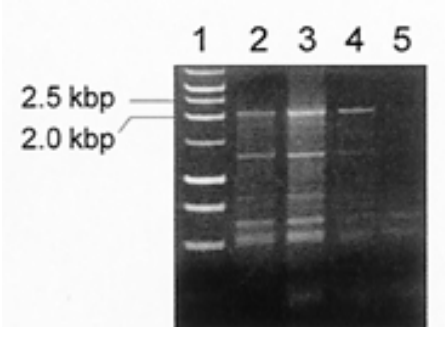

Fig. 3. A, Electrophoretic analysis in a $1 \%$ agarose gel of reverse-transcription polymerase chain reaction (RT-PCR) amplified products, using the CYSDV101 cucumber yellow stunting disorder virus (CYSDV)-specific oligonucleotide primer, a second arbitrary primer, and 5-, 10-, and 20-fold dilutions of cDNA template (lanes 2, 3, and 4, respectively). In lane 5, the second primer was omitted from the PCR reaction. B, RT-PCR amplification of the complete CYSDV coat protein (CP) gene from viral dsRNA, using virus-specific CP1 and CP2 oligonucleotide primers (lanes 2 and 3). Lane 1 contains DNA molecular size markers (Promega); sizes are indicated to the left of each panel. was added to each well, and optical density was measured after $1 \mathrm{~h}$ at $405 \mathrm{~nm}$ with a $v \cdot \max$ microplate ELISA reader (Molecular Devices, Sunnyvale, CA). ELISA plates were washed three times with PBS-T between each step.

\section{RESULTS}

Viral dsRNA analysis. dsRNA patterns identical to those described previously (24) were consistently observed in agarose gels and included two dsRNA species of 9 and $8 \mathrm{kbp}$, representing CYSDV RNA1 and RNA2, respectively (data not shown). CYSDV was detected in all samples, whereas BPYV was not detected in any of the samples tested after hybridization of dsRNA preparations with restricted, gel-extracted, and ${ }^{32} \mathrm{P}$-labeled CYSDV- or BPYV-specific probes (data not shown).

RT-PCR amplification. Oligonucleotide primer CYSDV4, which is coincident with the sequence of clone p410 (Fig. 1; 3), was used to prime first-strand cDNA synthesis with gel-extracted CYSDV dsRNA as template. After purification of the cDNA product, RTPCR amplification with a combination of CYSDV4 and a random primer generated a product of $\approx 2.2 \mathrm{kbp}$ (Fig. 2A, lane 3 ). DNA product of the same size was routinely generated with several dilutions of the cDNA reaction (data not shown) but was absent when the arbitrary primer was omitted from the PCR reaction (Fig. 2A, lane 2). Southern hybridization analysis with a virus-specific clone, pCYSDV (24), indicated the virus specificity of the product (Fig. 2B, lane 3), which also was confirmed by dideoxy sequence analysis. Similar RT-PCR experimentation was performed to amplify a fragment toward the CYSDV CP gene. The combination of CYSDV101 primer (Fig. 1) and arbitrary primer generated a virus-specific DNA product of $\approx 2.2 \mathrm{kbp}$ with several dilutions of cDNA template (Fig. $3 \mathrm{~A}$, lanes 2 to 4 ) that was absent when the arbitrary primer was omitted from the reaction (Fig. 3, lane 5). Likewise, in additional RT-PCR experiments, the CYSDV2 oligonucleotide primer and the same hexamer amplified a DNA fragment of $\approx 1.2 \mathrm{kbp}$ (data not shown) that included the $5^{\prime}$ end of the CYSDV HSP70 homolog gene (Fig. 1). The CP1 and CP2 oligonucleotide primers, which represented, respectively, the $5^{\prime}$ and $3^{\prime}$ ends of the putative CYSDV CP ORF, were used for RT-PCR amplification from viral dsRNA



Fig. 4. Tentative unrooted phylogenetic tree showing relative relationships between the amino acid sequences of known closterovirus coat proteins, using the CLUSTAL X program (31). For each internal node, bootstrap numbers higher than $60 \%$ (runs in which a node appeared) are indicated. BYSV = beet yellow stunt closterovirus; GLRaV = grapevine leafroll-associated virus- 3 and -2; BYV = beet yellows closterovirus; LIYV = lettuce infectious yellows virus; SPCSV = sweet potato chlorotic stunt virus; CYSDV = cucumber yellow stunting disorder virus; $\mathrm{LChV}=$ little cherry virus; $\mathrm{CTV}=$ citrus tristeza virus. 
template. A PCR product of the expected size (775 nt) was amplified (Fig. 3B, lanes 2 and 3), and its sequence was identical to that of the putative CYSDV CP gene.

Nucleotide and amino acid sequence comparisons. Computerassisted sequence analysis of the cloned fragments provided the nucleotide sequence information for four complete CYSDV genes and one incomplete gene, in a contiguous arrangement similar to that found in LIYV RNA2 (Fig. 1). The first three ORFs are 1,659, 1,524 , and $240 \mathrm{nt}$ long in a $5^{\prime}$ to $3^{\prime}$ orientation and potentially encode proteins with deduced molecular masses of 62,58 , and $9 \mathrm{kDa}$, respectively. The sequence of the fourth ORF, representing the putative CP gene, is part of the CYSDV101-generated RT-PCR product (Fig. 2A, lane 3) and coincides with the RT-PCR product amplified with the CYSDV CP1 and CP2 oligonucleotide primers (Fig. 3B, lanes 2 and 3). The complete nucleotide sequence of the $\mathrm{CP}$ coding region has been deposited in the GenBank database under accession no. AJ243000 and is not duplicated here. The putative CYSDV CP ORF, which is $756 \mathrm{nt}$ long and encodes a protein with a deduced molecular mass of $28,478 \mathrm{Da}$, is followed immediately down-

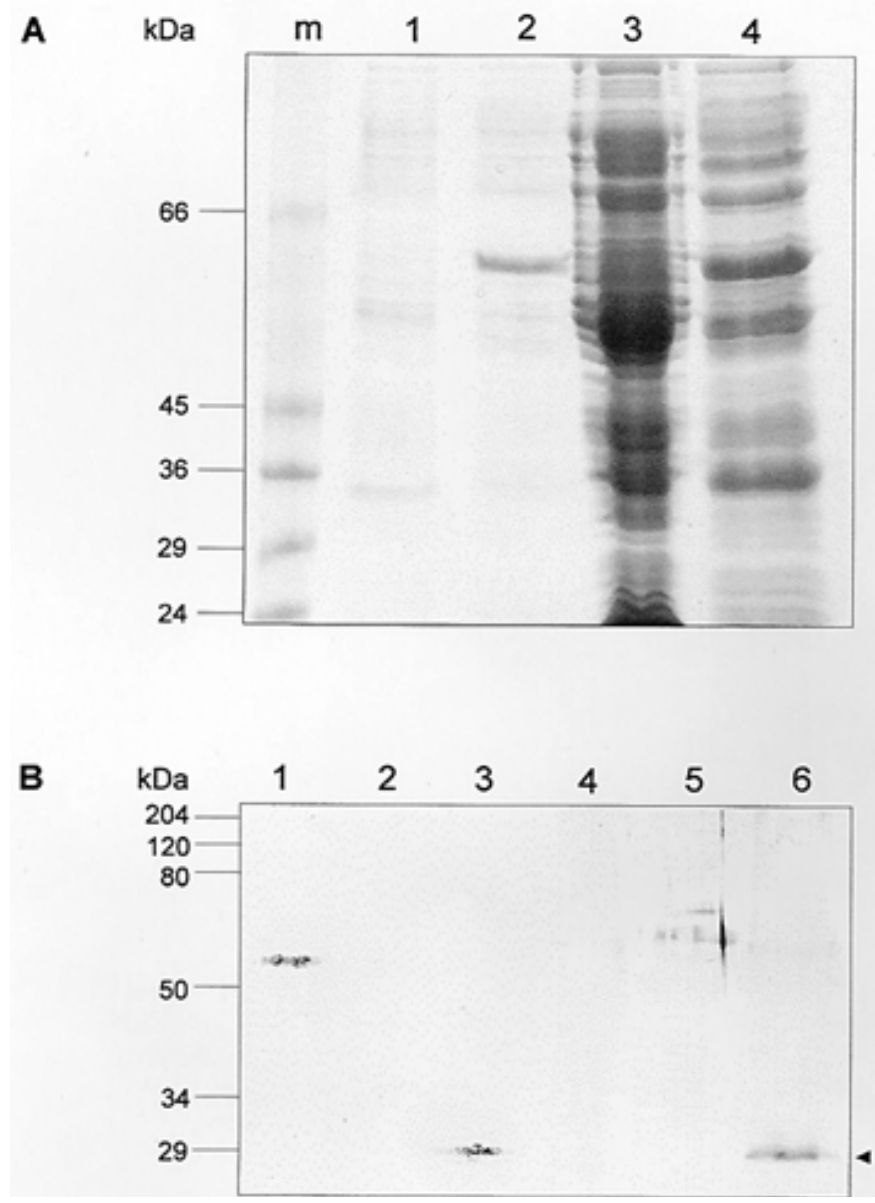

Fig. 5. A, Ten percent sodium dodecyl sulfate-polyacrylamide gel electrophoresis (SDS-PAGE) of proteins from induced (lanes 2 and 4) and uninduced (lanes 1 and 3) Escherichia coli BL21 cells transformed with pGEXCYSDVCP plasmid. After induction and sonication, bacterial lysates were centrifuged to produce a pellet (lanes 1 and 2) and supernatant (lanes 3 and 4). Protein molecular weight markers (lane m) (Dalton Mark 7L, Sigma Chemical Co.) are indicated to the left. B, Immunoblot analysis of proteins after $12 \%$ SDS-PAGE of samples from induced BL21 cells carrying pGEX-CYSDVCP plasmid (lane 1), uninduced BL21 cells carrying pGEX-CYSDVCP plasmid (lane 2), purified cucumber yellow stunting disorder virus coat protein (CYSDV CP) after digestion of the GST-CYSDVCP fusion protein with thrombin protease (lane 3), beet pseudo-yellows virus-infected cucumber extract (lane 4), healthy melon extract (lane 5), and CYSDV-infected melon extract (lane 6). Positive reactions of anti-GST-CYSDVCP serum with CYSDV CP are indicated with an arrowhead. Prestained, broad-range protein molecular weight markers (Bio-Rad Laboratories) are shown to the left. stream by the CYSDV CPd ORF for which N-terminal sequence data was obtained (I. C. Livieratos and R. H. A. Coutts, unpublished data).

A PileUp alignment of the deduced sequence of 251 amino acids in the CYSDV CP with all known closterovirus CPs revealed four perfect matches, including the invariant Arg (R) and Asp (D) residues that identify the salt bridge structure conserved in CPs of filamentous viruses (8; data not shown). The same alignment showed that CYSDV CP shares higher levels of similarity with SPCSV and LIYV (36 and 26\%, respectively), suggesting that the whiteflytransmitted closteroviruses form an evolutionarily distinct cluster (Fig. 4).

Serological studies of the CYSDV CP gene. The CP1 and CP2 oligonucleotide primers used in RT-PCR amplified a DNA product that contained the putative CYSDV CP ORF (Fig. 3B, lanes 2 and 3). This DNA fragment was cloned in frame in a GST fusion vector (pGEX-KG) and was expressed in E. coli bacterial cells. After induction with isopropyl- $\beta$-D-thiogalactopyranoside at $25^{\circ} \mathrm{C}$, BL21 cells transformed with pGEX-CP overexpressed an additional $55-\mathrm{kDa}$ protein that was absent from uninduced control cells (Fig. 5A, compare lanes 3 and 4). Most of the overexpressed protein was present in the soluble fraction of the bacterial lysates (Fig. 5A, compare lanes 2 and 4) and had a molecular mass of the expected size of the fusion protein, i.e., GST-CYSDVCP $(54.5 \mathrm{kDa})$. Affinity purification of the fusion protein from cleared lysates with a Sepharose 4B matrix was unsuccessful, so the protein was purified further to near homogeneity by SDS-PAGE and electroelution as described above. To confirm the identity of the CYSDV CP ORF and the specificity of the antisera raised against the fusion protein, immunoblot analysis of total protein extracts from CYSDV-infected and healthy melon plants, as well as BPYV-infected cucumbers, was performed (Fig. 5B). The antiserum raised against the GST-CYSDVCP fusion protein reacted strongly and specifically with a CYSDV CP band of $\approx 28.5 \mathrm{kDa}$ present exclusively in CYSDVinfected plants (Fig. 5B, lane 6). No cross-reactions were observed when the preimmune serum was used in identical blots (data not shown). Minor cross-reactions were noted with a high molecular

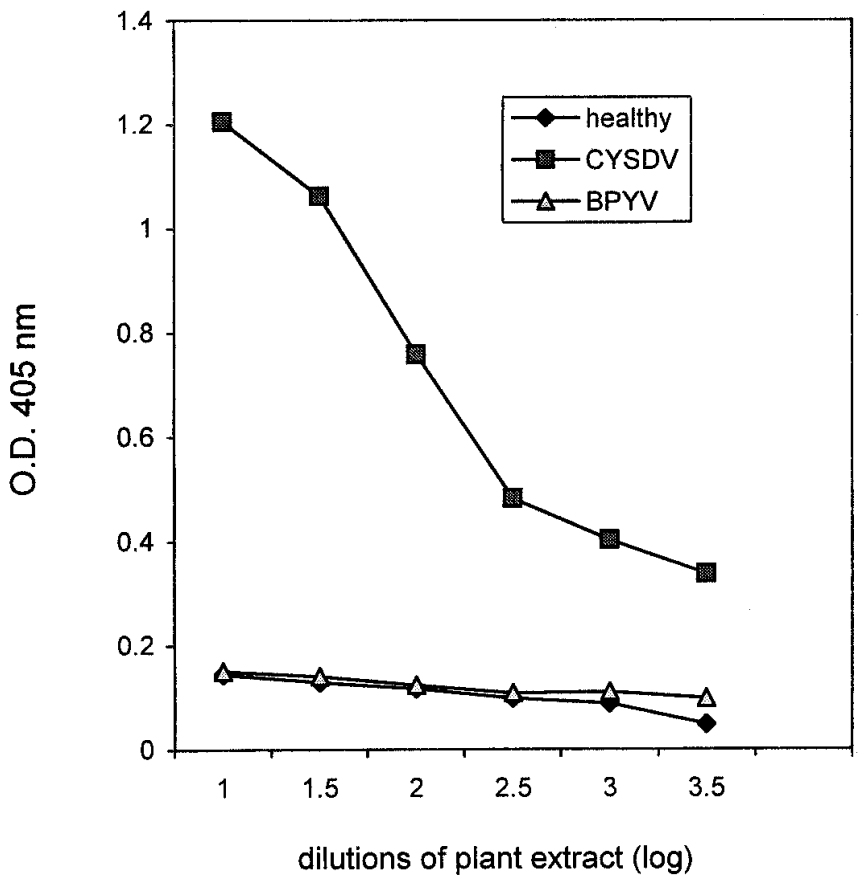

Fig. 6. Indirect enzyme-linked immunosorbent assay detection of cucurbit yellow stunting disorder virus (CYSDV) in infected melon extracts using antiGST-CYSDVCP serum (dilution of 1:500). Dilutions of plant extracts are indicated as logarithmic values. Each measurement is an average of the readings from three wells. BPYV = beet pseudo-yellows virus. 
weight protein in all of the plant extracts (Fig. 5B, lanes 4 through 6). Polyclonal antisera had a titer of $2 \times 10^{3}$ in indirect ELISA tests and were calculated from the highest dilution of the antiserum at which the signal was at least threefold higher than the signal produced with the respective healthy control extract (Fig. 6). A comparison of the titers in immunoblot and ELISA assays showed a twofold higher sensitivity of antisera in the former.

\section{DISCUSSION}

The progressive displacement of $T$. vaporariorum by $B$. tabaci in southeastern Spain over the last few years is reflected in the incidence of yellowing closteroviruses in the area. As a result, BPYV, which was previously the most prevalent virus now appears to be restricted, while CYSDV appears to be the predominant whiteflytransmitted virus on cucurbits. Severe outbreaks of CYSDV infections on greenhouse-grown cucurbits in the Almeria Region of Spain translates to millions of dollars in losses every year and places CYSDV amongst the most important pathogens of cucurbit crops in the Mediterranean Region. In this paper, we used previously determined sequence information on the CYSDV HSP70 homolog gene (3) and devised a modified RT-PCR protocol to target the CP gene of the virus in an attempt to clone it and subsequently produce a polyclonal antiserum against it that can be used for routine diagnosis of the virus.

After reverse-transcription of highly purified, gel-extracted viral dsRNAs, cDNA served as template for combined PCR amplification with a specific oligonucleotide primer and a random hexamer as an anchor secondary primer. Relatively large virus-specific DNA products were amplified routinely in both strand orientations with several concentrations of cDNA template. RT-PCR fragments were not generated when the arbitrary hexamer was omitted from PCR reactions (Fig. 2A, lane 2; Fig. 3A, lane 5). The virus specificity of the products was monitored initially by molecular hybridization (Fig. 2B) with CYSDV-specific probes that shared overlapping sequences with the amplified products (Fig. 1) and subsequently was confirmed by sequencing. As a result, combined nucleotide sequence information was obtained for the complete HSP70, p58, p9, and CP ORFs and the incomplete CPd ORF (I. C. Livieratos and R. H. A. Coutts, unpublished data). The arrangement of genes was similar to that found on LIYV RNA2 (18), including the relative positions of the $\mathrm{CP}$ and $\mathrm{CPd}$ genes, which are in a reversed orientation compared with monopartite aphid-transmitted closteroviruses (19).

The CYSDV CP gene is $756 \mathrm{nt}$ long and encodes a protein with a molecular mass of $\approx 28.5 \mathrm{kDa}$. Multiple sequence alignments of all known closterovirus CP sequences, using the PileUp program, revealed only limited amino acid similarities. However, the invariant $\mathrm{R}$ and $\mathrm{D}$ residues, which are conserved in all CPs of filamentous viruses, were present (8; data not shown). Amino acid-based alignment of the CYSDV CP with the homologous proteins of other closteroviruses revealed higher levels of similarity among whitefly-transmitted closteroviruses (SPSCV and LIYV), suggesting closer phylogenetic relationships of these viruses compared with aphid- or mealybug-transmissible closteroviruses. In phylogenetic comparisons of closterovirus CPs (Fig. 4), monopartite BYV, CTV, BYSV, and GLRaV-2 clustered in one main branch with GLRaV-3 and little cherry virus as outgroups, whereas CYSDV and bipartite criniviruses LIYV and SPCSV clustered in another branch, confirming their taxonomy as a separate genus (25).

The putative CP ORF was RT-PCR amplified from dsRNA templates by $\mathrm{CP} 1$ - and $\mathrm{CP} 2$-specific primers and subsequently cloned in a GST expression vector. The GST-CYSDVCP fusion protein was used for antiserum production. Anti-GST-CYSDVCP polyclonal antiserum specifically detected the CYSDV CP in immunoblots (Fig. 5B) and ELISA tests (Fig. 6) and confirmed its identity. The titer of the antisera in immunoblots was twofold higher than in the ELISA assay, suggesting preferential detection of denatured
CYSDV CP. The antiserum against the CYSDV CP specifically detected the $\mathrm{CP}$ of the virus in infected plant extracts both in immunoblots and ELISA tests, was reliable, and could be used in large epidemiological studies of this emerging Crinivirus.

\section{ACKNOWLEDGMENTS}

We thank The Greek State Scholarship Foundation for their support of I. C. Livieratos and P. Kraakman (De Ruiter Research, Almeria, Spain) and J. Lambalk (Enza Zaden, Enkhuizen, the Netherlands) for supplying plant material.

\section{LITERATURE CITED}

1. Agranovsky, A. A. 1996. Principles of molecular organization, expression, and evolution of closteroviruses: Over the barriers. Adv. Virus Res. 47:119-158.

2. Agranovsky, A. A., Koenig, R., Maiss, E., Boyko, V. P., Casper, R., and Atabekov, J. G. 1994. Expression of the beet yellows closterovirus capsid protein and $\mathrm{p} 24$, a capsid protein homologue, in vitro and in vivo. $\mathrm{J}$. Gen. Virol. 75:1431-1439.

3. Celix, A., Lopez-Sese, A., Almarza, N., Gomez-Guillamon. M. L., and Rodriguez-Cerezo, E. 1996. Characterization of cucurbit yellow stunting disorder virus, a Bemisia tabaci-transmitted closterovirus. Phytopathology 86:1370-1376.

4. Clark, M. F., and Adams, A. N. 1977. Characteristics of the microplate method of enzyme-linked immunosorbent assay for the detection of plant viruses. J. Gen. Virol. 34:475-483.

5. Coffin, R. S., and Coutts, R. H. A. 1995. Relationships between Trialeurodes vaporariorum-transmitted yellowing viruses from Europe and North America. J. Phytopathol. 143:375-380.

6. Coutts, R. H. A., and Coffin, R. S. 1996. Beet pseudo-yellows virus is an authentic closterovirus. Virus Genes 13:179-181.

7. Deveraux, J., Haeberli, P., and Smithies, O. 1984. A comprehensive set of sequence analysis programs for the VAX. Nucleic Acids Res. 12:387-395.

8. Dolja, V. V., Boyko, V. P., Agranovsky, A. A., and Koonin, E. V. 1991. Phylogeny of capsid proteins of rod-shaped and filamentous RNA plant viruses: Two families with distinct patterns of sequence and probably structure conservation. Virology 184:79-86.

9. Duffus, J. E. 1965. Beet pseudo-yellows virus, transmitted by the greenhouse whitefly (Trialeurodes vaporariorum). Phytopathology 55:450-453.

10. Duffus, J. E., Larsen, R. C., and Liu, H. Y. 1986. Lettuce infectious yellows virus-A new type of whitefly-transmitted virus. Phytopathology 76:97-100

11. Duffus, J. E., Liu, H.-Y., and Wisler, G. C. 1994. Lettuce chlorosis virusA new whitefly-transmitted closterovirus. Eur. J. Plant Pathol. 102:591-596.

12. Gish, W., and States, D. J. 1993. Identification of protein coding regions by database similarity search. Nat. Gen. 3:266-272

13. Hassan, A. A., and Duffus, J. E. 1991. A review of a yellowing and stunting disorder in the United Arab Emirates. Emir. J. Agric. Sci. 2:1-16.

14. Hoyer, U., Maiss, E., Jelkmann, W., Lesemann, D.-E., and Vetten, H. J. 1996. Identification of the coat protein gene of a sweet potato sunken vein closterovirus isolate from Kenya and evidence for a serological relationship among geographically diverse closterovirus isolates from sweet potato. Phytopathology 86:744-750.

15. Jorda-Gutierrez, D., Gomez-Guillamon, M. L., Juarez, M., and Alfaro-Garcia, A. 1993. Clostero-like particles associated with a yellowing disease of melons in southeastern Spain. Plant Pathol. 42:722-727.

16. Karasev, A. V., Nikolaeva, O. V., Lee, R. F., Wisler, G. C., Duffus, J. E., and Dawson, W. O. 1998. Characterization of the beet yellow stunt virus coat protein gene. Phytopathology 88:1040-1045.

17. Klaassen, V. A., Boeshore, M., Dolja, V. V., and Falk, B. W. 1994. Partial characterization of the lettuce infectious yellows virus genomic RNAs, identification of the coat protein gene and comparison of its amino acid sequence with those of other filamentous RNA plant viruses. J. Gen. Virol. 75:1525-1533.

18. Klaassen, V. A., Boeshore, M. L., Koonin, E. V., Tian, T., and Falk, B. W. 1995. Genome structure and phylogenetic analysis of lettuce infectious yellows virus, a whitefly-transmitted bipartite closterovirus. Virology 208:99110 .

19. Koonin, E. V., and Dolja, V. V. 1993. Evolution and taxonomy of positive-strand RNA viruses: Implications of comparative analysis of amino acid sequences. Crit. Rev. Biochem. Mol. Biol. 28:375-430.

20. Laemmli, U. K. 1970. Cleavage of structural proteins during the assembly of the head of bacteriophage T4. Nature (Lond.) 227:680-685.

21. Lee, C., Levin, A., and Branton, D. 1987. Copper staining: A five-minute protein stain for sodium dodecyl sulfate-polyacrylamide gels. Anal. Biochem. 166:308-312. 
22. Leppard, K., Totty, N., Waterfield, M., Harlow, E., Jenkins, J., and Crawford, L. 1983. Purification and partial amino acid sequence analysis of the cellular tumour antigen, p53, from mouse SV-40-transformed cells. EMBO J. 2:1993-1999.

23. Ling, K.-S., Zhu, H.-Y., Jiang, Z.-Y., McFerson, J. R., and Gonsalves, D. 1997. Using antibodies developed against recombinant coat protein to detect grapevine leafroll associated closterovirus-3 (Abstr.) Phytopathology 87(suppl.):S58.

24. Livieratos, I. C., Katis, N., and Coutts, R. H. A. 1998. Differentiation between cucurbit yellow stunting disorder virus and beet pseudo-yellows virus by a reverse-transcription-polymerase chain reaction assay. Plant Pathol. 47:362-369.

25. Mayo, M. A., and Pringle, C. R. 1997. Virus Taxonomy. J. Gen. Virol. 79:649-657.

26. Nikolaeva, O. V., Karasev, A. V., Gumpf, D. J., Lee, R. F., and Garnsey, S. M. 1995. Production of polyclonal antisera to the coat protein of citrus tristeza virus expressed in Escherichia coli: Application for immunodiagnosis. Phytopathology 85:691-694.

27. Pio-Ribeiro, G., Winter, S., Jarret, R. L., Demski, J. W., and Hamilton, R. I. 1996. Detection of sweet potato virus disease-associated closterovirus in a sweet potato accession in the United States. Plant Dis. 80:551-554.

28. Pringle, C. R. 1996. Virus Taxonomy 1996-A Bulletin from the 10th International Congress of Virology in Jerusalem. Arch. Virol. 141:2251-2256.

29. Sambrook, J., Fritsch, E. F., and Maniatis, T. 1989. Molecular Cloning: A Laboratory Manual. 2nd ed. Cold Spring Harbor Laboratory, Cold Spring Harbor, NY.

30. Sung, Y. K., and Coutts, R. H. A. 1995. Potato yellow mosaic geminivirus AC2 protein is a sequence non-specific DNA binding protein. FEBS Lett. 383:51-54.
31. Thompson, J. D., Gibson, T. J., Plewniak, F., Jeanmougin, F., and Higgins, D. G. 1997. The CLUSTAL X windows interface: Flexible strategies for multiple sequence alignment aided by quality analysis tools. Nucleic Acids Res. 25:4876-4882.

32. Tian, T., Soong, J., Wisler, G. C., Duffus, J. E., and Falk, B. W. 1996. Generation and cloning of specific cDNAs corresponding to four whiteflytransmitted viruses using RT-PCR and degenerate primers corresponding to the closterovirus gene encoding the heat shock protein 70 homolog. Phytopathology 86:1167-1173.

33. Towbin, H., Staehelin, T., and Gordon, E. 1979. Electrophoretic transfer of proteins from polyacrylamide gels to nitrocellulose sheets: Procedure and some applications. Proc. Natl. Acad. Sci. USA 76:4350-4354.

34. Wisler, G. C., Duffus, J. E., Liu, H.-Y., and Li, R. H. 1998. Ecology and epidemiology of whitefly-transmitted closteroviruses. Plant Dis. 82:270280.

35. Wisler, G. C., Li, R. H., Liu, H.-Y., and Duffus, J. E. 1997. Partial molecular and cytological characterisation of tomato chlorosis virus. (Abstr.) Phytopathology 87(suppl.):S104.

36. Wisler, G. C., Liu, H.-Y., Duffus, J. E., and Falk, B. W. 1996. Tomato infectious chlorosis virus has a bipartite genome and induces phloem-limited inclusions characteristic of closteroviruses. Phytopathology 86:622-626.

37. Woudt, L. P., deRover, A. P., de Haan, P. T., and van Grinsven, M. Q. J. M. 1993. Sequence analysis of the RNA genome of cucumber chlorotic spot (CCSV), a whitefly-transmitted closterovirus. Page 326: Abstr. 9th Int. Congr. Virol., Glasgow, Scotland.

38. Yamashita, S., Doi, Y., Yora, K., and Yoshino, M. 1979. Cucumber yellows virus: Its transmission by the greenhouse whitefly, Trialeurodes vaporariorum (Westwood) and the yellowing disease of cucumber and muskmelon caused by the virus. Ann. Phytopathol. Soc. Jpn. 45:4584-4596. 